\title{
Geography Taught as if It Matters
}

\author{
Stephen J. Thornton \\ University of South Florida
}

\begin{abstract}
Nel Noddings $(2013,2015)$ argues there is no school subject more crucial than geography for making "better adults" who will serve as caring and responsible stewards of planet Earth. This perspective assigns geography a far greater role in school (and college) programs than in many places today. In this essay, I elaborate what such a perspective could mean. Specifically, I explore how relationships-both among humans and in subject matter-enable a geographic education that reaches young people. As touchstones for discussion, I draw on two propositions Noddings repeatedly advances: (1) geography considered as a study of the earth as the "home" of humans and other living things provides a sound basis for the selection of topics for study, and (2) children's interests "employed wisely will lead to knowledge and attitudes that are adequate for personal fulfillment and for citizenship" (Noddings, 2012, p. 194).
\end{abstract}

Keywords: geography, social studies, student interests, thematic instruction, relationships

ISSN 2560-8371

DOI: 10.24908/encounters.v20i1.13422

(C) Encounters in Theory and History of Education | 69 


\section{La géographie enseignée comme si elle était importante}

\section{Résumé}

Nel Noddings insiste sur une «vision plus riche et plus brillante» pour les écoles. Dans cet article, j'explique ce que signifie une telle vision pour un secteur d'étude scolaire négligé, la géographie. Spécifiquement, j'explore comment les relations, tant entre les humains qu'en la matière scolaire, permettent une éducation géographique qui rejoint les jeunes. Comme point de référence pour la discussion, je me base sur deux propositions que Noddings avance à plusieurs reprises: (1) la géographie, considérée comme étude de la terre et «foyer» des humains et des autres êtres vivants, fournit une base solide pour choisir les thèmes à étudier, et (2) les intérêts des enfants «employés sagement vont mener aux connaissances et attitudes adéquates pour la réalisation personnelle et la citoyenneté». (Noddings, 2012, p. 194).

Mots-clés: la géographie; les études sociales; les intérêts des étudiants; l'instruction thématique; les relations

\section{La geografía enseñada como si importara}

\section{Resumen}

Nel Noddings (2015) insta a una "visión más rica y brillante" para las escuelas. En este ensayo, explico lo que significa tal visión para un campo de estudio escolar descuidado, la geografía. Específicamente, exploro cómo las relaciones, tanto entre los humanos como en la materia, permiten una educación geográfica que llega a los jóvenes. Como puntos de referencia para la discusión, me baso en dos proposiciones que Noddings avanza repetidamente: (1) la geografía considerada como el estudio de la tierra como el "hogar" de los seres humanos y otros seres vivos que proporciona una base sólida para la selección de temas para el estudio, y (2) los intereses de los niños que "empleados sabiamente conducirán a conocimientos y actitudes adecuadas para la realización personal y la ciudadanía” (Noddings, 2012, p. 194).

Palabras clave: geografía, estudios sociales, intereses de los estudiantes, instrucción temática, relaciones

70 | Encounters 20, 2019, 69-82 


\section{Has Geography Mattered?}

Geography is about place and environment as history is about time and events (Gregg \& Leinhardt, 1994). It concerns how humans-as individuals and in social groups - live on earth, how they use and navigate space as they shape their environments and are conditioned by those same environments. On its face, no school subject sounds more fundamental to education. Yet, geography suffers from academic neglect and is often dismissed by otherwise well-educated persons as of little intellectual significance; even educators sometimes regard it as a listless pursuit, "just geography" as one student teacher declared (see Gaudelli \& Patterson, 2013).

If we cared about geography, what would we teach? Simply put, why should we teach $\mathrm{x}$ rather than $\mathrm{y}$ ? Is the study of the local area more valuable than distant shores? Is proficiency in map reading more important than the ability to bring to mind images of natural landscapes? Should global awareness be a required outcome? Given limited time for what are, after all, countless geographic concepts and relationships, which ones warrant inclusion in instructional programs? How do we decide? Who should decide?

Consistent with an ethic of care, Noddings (2003) answers these questions in relational terms in which she includes the interpersonal aspects of classroom life as well as relationships in the subject matters of the curriculum. Accordingly, topics selected for geographic study would not merely be about "about" how we live individually and together in communities but, ideally, also exhibit promise to "enhance" individual growth and community bonds (p. 255).

Her position derives from not only an ethic of care but also draws appreciatively from progressive educational thought as exemplified by, for example, John Dewey (1916) and Lucy Sprague Mitchell (1991), both of whom assign geography a central place in the school curriculum; Mitchell even wondered whether "modern geography should not be regarded as a separate subject but as a point of view which can color many subjects" (p. 20). Its most obvious connections are to history, civics, and the social sciences, a combination of subject areas, which after the 1920s, was increasingly referred to as "social studies" in the United States and a number of other nations, particularly around the Pacific Rim (Thornton, 2019).

Although we hope, as Maxine Greene (1995) pithily remarks, that the young "grasp the shapes of our geography, the story of our democracy" (p. 188), classroom cases where this finds meaningful expression in geography or other social studies have seldom been as common as would be ideal (Barton \& Avery, 2016; Brophy, 1993). Although authorities may assign considerable importance to geographic subject matter, the fact remains that as typically presented it leaves many young people cold, lacking apparent connection to their lives.

While geography occupied a respectable share of the curriculum in early public schooling, even by Dewey's time its reputation was associated with the some of the 
worst features of 19th-century education in its stress on recitation of disconnected information. In reaction, Dewey (1990) made the incontrovertible observation that geography is, already, involved in what children "see, feel and touch every day" (p. 76), however, they seldom recognize the connection of these everyday experiences to geographic study in schools. As in all his educational writings, dichotomies bothered Dewey:

When we think that we all live on earth, that we live in an atmosphere, that our lives are touched at every point by the influences of the soil, flora, and fauna, by consideration of light and heat, and then think of what the school study of geography has been, we have a typical idea of the gap existing between the everyday experiences of the child and the isolated material supplied in such large measure by the school. (p. 76)

In contrast to this disconnection stand examples of lively, connected geographyflowing over into historical and civic concerns-and how it worked in the classroom. For instance, Dewey and his daughter, Evelyn (Dewey \& Dewey, 1962), observed a lesson on how locks work in the (then-new) Panama Canal that failed to arouse student interest. By a change of method, presenting a problem to be solved-How could the U.S. defend its Pacific coast and Hawaii when its navy was mainly in the Atlantic? - the students "at once became interested" (p. 58). The interest quickly extended to genuine engagement with the previously shunned question of how locks work (p. 58). Adopting a similar approach, contemporary scholars Li-Ching Ho and Tricia Seow (2013) demonstrate, for example, how geography lessons can connect local spaces of "Chinatowns" to matters of global significance. Related examples are not hard to find (e.g., Varga, Beck, \& Thornton, 2019).

At the start of the 20th century-although its subject-matter emphasis sometimes seems to have been disconnected facts - the curricular status of geography was still higher than it was by the century's end. In the meantime, it is possible to identify any number of notable innovations in geographic education, although whether many of them had lasting positive effects on school geography remains debated. The High School Geography Project of the 1960s is a case in point (e.g., see Helburn, 1998; Schmidt, 2010). One could also point to burgeoning enrollment in Advanced Placment Human Geography. Nonetheless, 21st-century philosopher of social science D.C. Phillips (2016) reports geography had undergone "something of a reversal of fortune" by which it "has almost ceased to exist as a separate academic field and consequently as a subject in the school curriculum" (p. 121). While this obituary may be overstatement, there is little doubt that in addition to its decline in higher education the study of geography has become increasingly marginalized in the policies and practices of elementary and secondary education. 


\section{What Geographic Education Has Been}

Geography educators sometimes blame the rise of social studies for the decline of geography. They may have a point as social studies as a field has generally afforded most weight to history and civics. But there seems more to the malaise. At the outset, the architects of social studies presented geography, history, and civics as partners in the new enterprise. While some geographic educators and geographers accepted this tacit invitation, others warily distanced themselves from social studies. Geographers in higher education, in contrast somewhat to political scientists and especially to historians, tended to stand apart from efforts at school curriculum reform (Schulten, 2001). This distance, along with the decline of geography in higher education noted above, seem likely explanations for it in many places losing ground in schools as either a social study or as an autonomous subject.

For example, although authorities routinely urge-even mandate-meaningful integration of geography with history, in practice this integration seldom seems to rise above superficiality or is simply ignored (see Thornton, 2007). One obvious reason for this outcome is that even teachers who complete a full-blown teacher education program, which in the United States at least is much less common than in the past, and, further, if one or two geography courses is part of that program, "typically, these courses are introductory-level aimed at either a general education audience or intended as a first course in a major" (Boehm, Solem, \& Zadrozny, 2018, p. 127). How much more relevant might it be if it were a dedicated course organized around concepts and principles directly useful for developing and teaching geography and related subjects as captured in the phrase, "geographic approaches to social education" (Kohn, 1948)?

As a rule, pedagogy in geography falls along a curricular continuum stretching from an instructional emphasis on facts to an emphasis on meaning (Thornton \& Wenger, 1990). Debate about the proper place to stand in this debate was pendulum-like across the 20th century (Bednarz \& Bednarz, 1992). At one extreme was the view that the most fundamental task geography should accomplish is instilling facts. At the other extreme lay arguments for a relational, cognitively-complex geography, to which we will return below. Relatively few educators occuped either extreme, of course, because all along thoughtful educators recognized that you could hardly have the one without the other-the real question was what part each was to play in method. Nonetheless the debate consumes precious energy and undermines attempts at reaching consensus on the directions geographic education should take.

The factual perspective is sometimes called "locational geography." It has always had its academic defenders on grounds such as "cultural literacy" (Hirsch, 1987). But, significantly, defenders of locational geography often hail from neither academic geography nor geographic education, nor social studies education for that matter. Rather, its impetus often comes from the likes of school boards, legislators, and the 
general public, who may lack a refined sense of geography, but nonetheless believe they know what geographic knowledge is: sundry facts and loosely associated skills count as geographic "knowledge." Snippets of this approach I have encountered include: "How many degrees south of the Equator is the Tropic of Capricorn?"; "Name two countries in Asia that experience the monsoon"; and "Mark the Humboldt Current on a world map." Patterns, order, regularities and irregularities on or near the earth's surface and the dynamic physical and human forces that account for them are absent or coincidental in this formulation of geography. Place-location and related conceptions of geographic knowledge are bolstered in many minds by the results of public opinion polls that suggest students-and the general public for that mattercannot identify the location of even places where the nation is at war.

The curricular consequence of the belief that geography concerns little more than low-level information more suited to trivia contests than serious cognitive activity can be rudimentary exercises such as, in the United States, memorizing the names of the capital cities of all 50 states. Comparable exercises can and do occur in other countries, too. Geography bees, sometimes sponsored by declared champions of geographic education reform such as the National Geographic Society, add further credence to the belief that geography is fact-driven and disconnected academic activity. Such efforts, intended to encourage interest in geography, become, a recent president of the American Association of Geographers (Bednarz, 2019) wryly remarks, a quest for "knowing the longest, deepest, smallest, or otherwise most exceptional feature in a category" (p. 110).

Emphasis on locational geography disconnected from meaningful contexts generally leaves students none the wiser about the possible significance of the material, or simply bored. With repetition, it becomes the kind of activity they associate with learning geography. For instance, consider an instructional activity I observed some years ago in which one of the objectives was to name the rivers bounding the state of lowa (Thornton \& Wenger, 1990). As far as I could ascertain, this attention to rivers and borders was new to the fourth-grade students. The teacher may have wanted the children to deduce the generalization that rivers could serve as convenient borders between states. While the children observed where rivers are located, they did not appear to connect this to "convenient" borders in the case of lowa in particular, let alone further afield.

To the children, the rivers and borders seemingly remained what Alfred North Whitehead (1929) referred to as "inert ideas": that is, "ideas that are merely received into the mind without being utilised, or tested, or thrown into fresh combinations" (pp. 1-2). The teacher, of course, could have driven home the relationship between rivers and their oft use as borders. Or the teacher might have built on the relationship by leading students to hypothesize whether other states are divided by rivers. Or they could have explored the significance of rivers in lowa in other respects. For instance, what might the presence of a plenitude of rivers imply for vulnerability to flooding? How 
have lowans responded to flooding? Are there seasons when the dangers are greater than other seasons? Why? Have towns and farms unwisely been located on flood plains? What should we do about it? Has flooding worsened since the land was reshaped by 19th-century white settlers? Locational facts are not inherently inert, Mitchell (1991) advised, but they need to be put to service as "the means to the discovery of significant relationships" (p. 4).

One countervailing force to facts that sometimes shapes school geography finds its justification in the discipline as it is understood in the academy. Since the 1980s, this force has found renewed vigor based on cognitive research, as it has come to be almost taken for granted that teaching and learning differ significantly in each subject area. From this perspective, both teachers and students are encouraged to "think like" a disciplinary scholar, a geographer in this case. Accordingly, the worth of school geography is judged by the degree to which it approximates an idealized version of what academicians in geography purport to do and think. At least in the case of school geography, however, there may be scant correspondence with today's "processoriented physical geography and geospatial technology" ascendant in many university geography departments (Boehm, Solem, \& Zadrozny, 2018, p. 127).

Even more important than the possible misalignment of school and university programs is that "thinking like" a geographer is hardly an encompassing educational goal. It makes no necessary provision for customary goals such as relevance of the subject matter to the demands of contemporary living, while reinforcing the tendency to ignore student interests. Nor does convincing evidence exist that the great majority of schoolchildren either want to or will significantly profit from thinking like a geographer (or historian, etc.). The mid-20th-century geographer Clyde F. Kohn (1982), who took a keen interest in both a coherent identity for the discipline of geography and in university-based geographers assuming some responsibility for their subject in schools, warned:

What geographers are researching and teaching at a particular time may be of great interest to them and to their professional colleagues, but may not be essential to a sound geographic program at the elementary and secondary grade levels. (p. 46)

Affirmation of the importance of authoritative disciplinary knowledge in a time of "alternative facts" notwithstanding, "thinking like a geographer" seems to assume that the educational goals of the subject can be identified by simple appeal to legitimated geographic knowledge and attitudes. But the subject of geography provides scant guidance on what children should study. Rather, such guidance requires stepping beyond the discipline to invoke, consciously or not, an educational rationale. What is more, the assumption that educational significance lies in the unfiltered content of academic disciplines can easily deflect us from the broad purposes that justify inclusion of the subject in the curriculum in the first place. These provisos constitute no 
brief for leaving geographers and other academicians out of deliberations about school curriculum - quite the contrary, they bring irreplaceable knowledge of what is currently important in the discipline which should inform academic schoolwork-but their perspective alone must be recognized as partial. The prime aim of geography in general education is not the production of juvenile geographers.

\section{Problems, Themes, and Projects}

What may be loosely described as either problems or themes as well as the use of projects present worthy alternatives to the traditional tour through a sequence of predetermined regions - such as "The United States and Its Neighbors" - in which any relationship to the experiences students bring to the class or to issues that currently matter in the world arises as a more or less fortuitous byproduct of study. Some years ago, cognitive researcher Susan Stodolsky (1988) convincingly showed "traditional teaching" in "more structured or ordered [social studies] fields" such as geography and history - far more than in teaching of the social sciences which often lends itself to teaching through problems and themes in group work - tends to skirt "problem solving and higher mental processes." It is likely, she further suggests, that "the conception of these subjects [geography and history] as collections of facts to be learned influences the cognitive goals of instruction" (p. 116).

Around the same time, geographers and geographic educators took a sharp turn away from traditional lists of geographic topics such as regions as the first step for developing instructional programs. The turning point is well-represented by the five geographic themes identified in Guidelines for Geographic Education (Committee on Geographic Education, 1984), which has subsequently been revised and expanded. The thematic approach in Guidelines, it should be noted, owed more to then prevailing beliefs about the discipline rather than actual personal and social problems of real life being suggested here as themes. Programs based on the five themes showed it is certainly possible to develop geography programs that incorporate attention to, for instance, "some end that interests" students (Watras, 2010, p. 796); however, relevance to the geographic themes was clearly paramount.

Problems and themes in the sense recommended here, on the other hand, prioritizes thinking about matters one cares about, thus minimizing the risk that classroom activities will drift toward covering and later recalling information. Moreover, since problems or themes can be approached from multiple perspectives, they nudge activities toward active learning in forms such as personal or group projects. Emphasis is then properly placed on the quality of the learning experience rather than on coverage of a preordained "important" material. Interest and relevance transform the character of geographic instruction. Even with a prescribed curriculum which is a 
laundry list of topics some latitude can generally be secured to take the direction being recommended here (Thornton, 2005).

Imagine, though, a more complete break with conventional curricular arrangements, where a class might pursue a broad theme. Consider "water." The class could be divided into groups with each group responsible for investigation of, say, a body of water at risk. There's agreement that cases for study should be from widely different parts of the planet so that the class can eventually place their cases in a global context. After some discussion, the class settles on three cases: Lake Chad in Africa, the Colorado River in western North America, and the Aral Sea in Central Asia. Notably, each of these bodies of water has radically shrunk in volume since the mid-20th century.

Take the Aral Sea, which is a particularly rich (and disturbing) topic that invites many types of valuable inquiries (Thornton, 2005). Inquiries might begin with exploring how human diversion of the major tributaries of the sea-it is technically speaking a lake because it has no ultimate outlet to the world's oceans - to irrigate crops caused the catastrophic fall in sea level, retreating miles from the old shoreline. A study could then be undertaken into the effects on microclimates and growing seasons around the perimeter of the reduced sea. What has happened to fishing and commerce on the sea as well as the health of the people who live around it (Strahler \& Strahler, 2000)? A marvelous exercise in hypothesis-making would be: Could the sea be restored to its former condition?

When the class comes together again, cross-case analysis occurs. Is the shrinkage of Lake Chad attributable at all to human activity like the Aral Sea, or is it wholly the product of forces beyond human control? What information would be required to answer the foregoing question? What is the Sahel and what is desertification? Can anything be done to stop the southward movement of the Sahara Desert? What would count as persuasive evidence in answering that question? How alike is the situation with the Colorado-as a river - to the situations of the two lakes? Since the Colorado often dries up before reaching its outlet in the Gulf of California because all of the water has been consumed (or evaporated), should it be considered a case of the same phenomenon as the shrinkage of the lakes or is it a different category of problem? Again, as with "restoring" the Aral Sea, the aim here is to foster thinking and problemsolving more than ending up with an authoritative answer.

Trying to construct satisfying answers to these questions may launch related inquiries. For example, how is the large urban population of semi-arid southern California supplied with water? What did the availability of water have to do with the growth of Los Angeles as a major urban center? What effects has this thirst for water had on the Colorado River and other exploited bodies of water, places, and landscapes? Lateral connections to other subject areas such as biography might also be pursued. For example, what of the troubling but fascinating biography of William Mulholland, who designed the Los Angeles Aqueduct which brought water from 
hundreds of miles away in the Owens Valley, which was robbed of its water resources to serve growing Los Angeles (Krist, 2018)? Or of John Muir, who earlier had fought to protect other valleys from destruction in order to supply water to growing San Francisco?

\section{Map Work}

Maps have long been regarded as the basic tool of geographic study. Although geographers are not the only users and makers of maps, mapping is intertwined with the identity of geography. But working with maps in classrooms, if occurring at all, tends to be reduced to exercises disconnected from the other parts of geographic study. This tendency is evident, for instance, in social studies textbooks beginning with a discrete chapter on map skills before getting to the topical chapters. Such an out-ofcontext method assumes students will store up the skills for later application, an assumption that is ill-founded. Further, experience suggests students generally find the skills exercise tedious. Although I would not entirely rule out the need for direct instruction on map skills, my interest here is more with using maps in manners consistent with the approach to geographic inquiry sketched in the last section. Specifically, I think Noddings (2013) is right when she points out:

It can be rewarding to let students of any age play with the tools and objects related to a unit of study. To play with maps, to measure distances, to imagine journeys can contribute substantially to learning and wise teachers can build on the interests that arise... (p. 98).

From this perspective, a primary purpose of map work is providing a venue for open-ended and speculative exploration, which requires some degree of "freedom" in order for "geographical imagination" to flourish (Bonnett, 2013, p. 99). Map work should be tied to student interest and curiosity and only occasionally when some clear need arises should devolve to direct attention to skills.

Maps should be an integral part of the thematic or problem-based method described above. To do so, however, more than comprehension of information answerable from maps is required. Map reading connotes comprehension of information directly supplied on a map - such as measuring the distance from Vancouver to Tokyo, locating the junction of the Mississippi and the Ohio rivers, and delineating the chief land-use zones of Australia. These tasks may or may not lead to more complex cognitive activity than mere decoding. Map interpretation, however, demands critical thinking. Although interpretation plainly demands some degree of comprehension, preoccupation with comprehension often becomes the endpoint of instruction rather than a point of departure for reasoning. 
Relationships which students discover for themselves with maps and relate to (and possibly modify) their personal topics of interest will normally be much more motivating to them than preset exercises in which their purposes may play no part. Better a relatively open-ended task such as providing students with rainfall and elevation maps of the California-Nevada region: What might they make of the great height of the Sierra Nevada in California? How much higher are they than the coastal ranges? Why is the westward slope of the Sierra Nevada moist and the leeward slope arid? Is there a name for this phenomenon? (If instructional time is scarce, the teacher can of course supply students with a few hints to speed up the process.)

What can be learned from and done with maps has, of course, grown more sophisticated with the development of geospatial technologies (Baker, Curtis, \& Millsaps, 2019); but caution is advised that these technologies not surrender the relational affordances of students together poring over maps, aerial photographs or measuring distances, and plotting best flying routes working with a large globe. In any case, the elemental basis of map work remains synonymous with Mitchell's (1991) more general observation about geographic learning: "the bearing of one fact on another fact...produces something different and added to the two separated facts-a relationship" (p. 4).

Map work should not, however, be restricted to study of what facts and relationships maps contain. It should also extend to treating maps as sources, and like other sources of knowledge they should be scrutinized. In the same spirit that we should never accept a primary-source historical document at face value, we should interrogate maps. Maps are something made and made by someone for some purpose. They are not an objective rendering of reality. Rather, all maps are selective representations of the features on the earth's surface they seek to represent. As geographer Mark Monmonier (1996) observes, "Maps, like numbers, are often arcane images accorded undue respect and credibility" (p. 3).

Thus, in addition to map reading and interpretation, maps should be scrutinized from a higher standpoint. To take an oft-cited case, the Mercator projection utilized so often in world maps exaggerates the area of land masses toward the poles at the expense of lands closer to the Equator. An effect of this distortion may be for map readers to assign greater significance to the wealthier nations on Earth, which are mostly in the higher latitudes. But there are countless, and likely less familiar, examples.

Take early modern European charts of the sub-Saharan African coast. Who made these maps and how did the rise of printing in Europe disseminate their perspectives to people who would never catch sight of Africa? What assumptions did these mapmakers bring to their work and how did this affect what was and was not included on the maps they produced? What did their early modern European maps portray or imply about the culture of Africa as they mapped its shoreline? How were these portrayals and implications interpreted by European printers? What might the possible 
consequences have been of this representation? Did the maps, as one scholar claims, "define a shift in European understandings of cultural difference" (Brotton, 2005, p. 138)?

\section{Conclusion}

There is no real dispute that geography is a fundamental element of how we navigate and interact with the environments of the world. As an already-cited geographer from Britain, Alistair Bonnett (2013), discerns, "Even if geography were to be dropped from every school and university curriculum some kind of illiterate geographical consciousness would blunder on" (p. 99). He rightly fears, however, that "blundering on" is no satisfactory alternative for substantial geographic education. Leaving such matters to chance or to trial and error removes an irreplaceable source of concepts, skills, and relationships necessary to make informed judgments on the critical issues of the day. This removal - what Elliot Eisner (2002) dubbed the "null curriculum" - is thus far from a neutral void. What one does not know, what one does not consider, what one does not even know exists can hardly constitute a part of critical thinking by an informed and caring citizenry in democratic societies. It is a void we cannot afford in an era of climate change and widespread environmental degradation. Nor, as Noddings (2013) implies and my personal observations seem to confirm, can we safely assume study of human-environmental relationships is taken care of in science courses such as biology or geology, as such courses may or may not provide significant consideration of particularities of places and patterns across space which are integral to education on Earth as the home of humans (p. 97).

Finally, it is tempting to propose as a simple remedy "more geography" to correct the problems I have identified; but alone that is probably no solution. Instead, it must be the right kind of geography accompanied by a relational pedagogy. The case must be made to policymakers and the public for the kind of geographic education sketched herein if it is to make a significant difference in the world.

\section{References}

Baker, T., Curtis, M., \& Millsaps, L. (2019). Geotechnologies and the spatial citizen. In E.E. Shin \& S.W. Bednarz (Eds.), Spatial citizenship education: Citizenship through geography, (pp. 117-131). New York, NY: Routledge.

Barton, K.C., \& Avery, P. (2016). Research on social studies education: Diverse students, settings, and methods. In D.H. Gitomer \& C.A. Bell (Eds.), Handbook of research on teaching (5th ed., pp. 985-1038). Washington, DC: American Educational Research Association. 
Bednarz, S.W. (2018). Best of times, worst of times: Geography education today. In P.G. Fitchett \& K.W. Meuwissen (Eds.), Social studies in the new education policy era: Conversations of purposes, perspectives, and practices (pp. 110-116). New York, NY: Routledge.

Bednarz, R.S., \& Bednarz, S.W. (1992). School geography in the United States: Lessons learned and unlearned. In A.D. Hill (Ed.), International perspectives on geographic education (pp. 139-154). Boulder, CO: Center for Geographic Education.

Boehm, R.G., Solem, M., \& Zadrozny, J. (2018). The rise of powerful geography. The Social Studies, 109, 125-135.

Bonnett, N. (2013). What is geography? London, UK: SAGE.

Brophy, J. (Ed.). (1993). Advances in research on teaching: Vol. 4, case studies of teaching and learning in social studies. Greenwich, CT: JAI Press.

Brotton, J. (2005). Printing the map, making a difference: Mapping the Cape of Good Hope, 1488-1652. In D.N. Livingstone \& C.W.J. Withers (Eds.), Geography and revolution (pp. 137-159). Chicago, IL: University of Chicago Press.

Committee on Geographic Education. (1984). Guidelines for geographic education: Elementary and secondary schools. Washington, DC: National Council for Geographic Education \& Association of American Geographers.

Dewey, J. (1990). The school and society and The child and the curriculum. Chicago, IL: University of Chicago Press.

Dewey, J. (1916). Democracy and education. New York, NY: Macmillan.

Dewey, J., \& Dewey, E. (1962). Schools of tomorrow. New York, NY: E.P. Dutton. Eisner, E.W. (2002). The educational imagination: On the design and evaluation of school programs (3rd ed.). Upper Saddle River, NJ: Merill, Prentice Hall.

Gaudelli, W., \& Patterson, T. (2013). "It's just geography": Critical geography and a critique of Advanced Placement Human Geography. In T.W. Kenreich (Ed.), Geography and social justice in the classroom (pp. 114-128). New York, NY: Routledge.

Greene, M. (1995). Releasing the imagination: Essays on education, the arts, and social change. San Francisco, CA: Jossey-Bass.

Gregg, M., \& Leinhardt, G. (1994). Mapping out geography: An example of epistemology and education. Review of Educational Research, 64, 311-361.

Helburn, N. (1998). The High School Geography Project: A retrospective view. The Social Studies, 89, 212-218.

Hirsch, E.D., Jr. (1987). Cultural literacy; What every American needs to know. Boston, MA: Houghton Mifflin.

Ho, L., \& Seow, T. (2013). Teaching geography through "Chinatowns": Global connections and local spaces. Social Education, 77, 36-41.

Kohn, C.F., (Ed.). (1948). Geographic approaches to social education. Washington, DC: Nation-al Council for the Social Studies. 
Kohn, C.F. (1982). Looking back: Working ahead. Journal of Geography, 81(2), 44-46.

Krist, G. (2018). The mirage factory: Illusion, imagination, and the invention of Los Angeles. New York, NY: Crown.

Mitchell, L.S. (1991). Young geographers: How they explore the world and how they map the world. New York, NY: Bank Street College of Education.

Monmonier, M. (1996). How to lie with maps (2nd ed.). Chicago, IL: University of Chicago Press.

Noddings, N. (2003). Happiness and education. Cambridge, UK: Cambridge University Press.

Noddings, N. (2012). Philosophy of education (3rd ed.). Boulder, CO: Westview Press. Noddings, N. (2013). Education and democracy. New York, NY: Teachers College Press.

Noddings, N. (2015). A richer, brighter vision for American high schools. New York, NY: Cambridge University Press.

Phillips, D.C. (2016). A companion to John Dewey's Democracy and Education. Chicago, IL: University of Chicago Press.

Schmidt, S. (2010). Geography education curriculum, history of. In C. Kridel (Ed.), Encyclopedia of curriculum studies (Vol. 1, pp. 405-406). Los Angeles, CA: SAGE.

Schulten, S. (2001). The geographical imagination in America, 1880-1950. Chicago, IL: University of Chicago Press.

Stodolsky, S.S. (1988). The subject matters: Classroom activity in math and social studies. Chicago, IL: University of Chicago Press.

Strahler, A., \& Strahler, A. (2000). Introducing physical geography (2nd. ed.). New York, NY: Wiley.

Thornton, S.J. (2005). Teaching social studies that matters: Curriculum for active learning. New York, NY: Teachers College Press.

Thornton, S.J. (2007). Geography in American history courses. Phi Delta Kappan, 88, 535-538.

Thornton, S.J. (2019). Geography as a social study: Its significance for civic competence. In E. E. Shin \& S.W. Bednarz (Eds.), Spatial citizenship education: Citizenship through geography (pp. 10-21). New York, NY: Routledge.

Thornton, S.J., \& Wenger, R.N. (1990). Geography curriculum and instruction in three fourth-grade classrooms. The Elementary School Journal, 90, 515-531.

Varga, B.A., Beck, T.A., \& Thornton, S.J. (2019). Celebrating Stonewall at 50: A culturally geographic approach to introducing LGBT themes. The Social Studies, 110, 33-42.

Watras, J. (2010). Social studies education. In C. Kridel (Ed.), Encyclopedia of curriculum studies (Vol. 2, pp. 795-798). Thousand Oaks, CA: Sage.

Whitehead, A.N. (1929). The aims of education and other essays. New York, NY: Macmillan. 